\section{Towards good land governance in Ukraine}

\author{
Kuryltsiv, Roman \\ Lviv National Agrarian University, Ukraine \\ kuryltsiv@ukr.net
}

SUMMARY

The article presents the analysis of transformation of land governance system in Ukraine and explores peculiarities of every component of that system. The carried investigation reveals problematic aspects and the ways for improvement of state land policy, land reform conducting, land management instruments applying and land administration system building to promote good governance in land sector of Ukraine.

Keywords: land governance, land resources, land policy, land reform, land management, land administration

\section{INTRODUCTION}

Traditionally land resources in Ukraine have been developed as a common property. In favor of national economic development land resources had to be over exploited. Such situation caused very high level of development of the country's life space. Over $90 \%$ of the territory was included to the sphere of economic employment. Only $8 \%$ of land resources is now in the natural state. The same situation is with the level of the plough lands. In our country they reach $54 \%$ (State Agency of Land Resources) but in well-developed European countries this parameter doesn't exceed 35\%. The structure of the country's land resources and land use witness rather considerable disproportions. Such disproportion development may become a serious danger for the environment and, thus, for the sustainable development of national economy.

There is a slight progress in modernizing governance in the land sector for the last years. However, progress is mainly technology driven and too often not accompanied by progress in reforming land policies, improving the normative framework, involving civil society, and reengineering institutional processes. It is therefore important to identify major land-related problems and also review the recommendations for continued land reform processes towards good land governance in Ukraine.

\section{LAND POLICY AND STRUCTURAL TRANSFORMATION IN LAND SECTOR}

Land policy is the fundamental principle of economic and social life. Land policy lies at the heart of economic and social life and environmental issues in all countries. Modern land policy in Ukraine starts from the implementation of land reform, which has passed through three stages of evolution:

1. The first stage (1988-1992) gave productive enterprises (farms, industrial and trade entities) independent management and self-financing. Land and property relations changed from unpaid state allocation of assets by unilateral grants to paid possession and use of assets under two-party lease contracts. Farm workers were recognized with collective ownership of the land and property objects. Citizens generally were recognized to have rights of life possession and inheritance in their small parcels of housing, garden, and recreational land.

2. In the second stage (1992-1999), collective ownership of farmland was transformed to common ownership (without delineation of land plots in nature). Each citizen/land share owner was allowed to lease his/ her shares to a farm enterprise or withdraw the share to work it as an independent (family) entrepreneur. Individual citizen rights in small parcels were recognized as ownership. Non-agricultural enterprises and entrepreneurs could transform their rights of possession to ownership or lease.

3. In the current third stage (2000-present), land shares of farmland are being transformed into citizen ownership by issuance of a State Act with or without delineation in nature and with the right to lease to a farm enterprise or work the land independently. Rights of disposition by sale or placement in an enterprise capital fund are withheld until 2013. Citizen ownership of small parcels can be defined as full civil law ownership (with unlimited disposition) by obtaining and registering a State Act.

Land transformations in Ukraine within the last two decades resulted in considerable changes in land relations, legal and territorial forms of land use and forms of land ownership. But in practice, its fundamental end goal - rational, effective and environmentally safe use of land resources and protection of land - has not been achieved. Due to the lack of funds for land management and protection of land against negative natural, anthropogenic and technogenic effects, restoration of fertility of soil, its quality is deteriorating, the productiveness of farming land at most enterprises remains low, land consumption in non-agricultural sectors is still high.

\section{LAND MANAGEMENT INSTRUMENTS}

All countries depending on their cultural basis and level of economic development have to deal with a variety of techniques and tools to manage its land and resources. Land management requires operational processes to implement land policies in comprehensive and sustainable ways. One of the basic land management instruments is land use planning, which foresees the development of national and regional programs of land use and conservation worked out according to the programs of economic, scientific, technical and social development of Ukraine. 
Planning of land use in Ukraine foresees zoning only within the settlements (lands outside the settlement not included). Such situation causes the violation of legal regime and condition of economic mechanism of land use as well as the ineffective application and complication of management of land and property complex of administrative areas.

Land development of rural territories as the system of rational land use organization and conservation, foundation of new land lots and arrangement of the real ones and fixing their boundaries in the terrain creates territorial preconditions for rational and sustainable usage of the whole land fund (Law "On Land Development, 2003).

Land development is the basic national instrument which guarantees ecologically safe and economically effective land use.

In particular it foresees:

- settling (reestablishment) in the terrain the boundaries of administrative and territorial areas, land owners and tenures;

- development of national and regional programs of land use and conservation;

- land surveying schemes, development of technical and economic arguments in favour of land use and conservation of considerable administrative and territorial areas;

- grounding of fixing boundaries of areas with particular ecological, recreational and wild life area regimes;

- development of plan of allotment of land plots;

- fixing in terrain boundaries of land plots;

- compilation of documents certifying the land ownership and tenure;

- development of plan which secures ecological and economic grounding of crop rotation, arrangements of areas and development of measures for land protection;

- authorized audit of the implementation of land use and land protection;

- topographic, geodetic, cartographic, soil, geobotanic and other researches and explorations.

State control of the land usage and conservation is secured by administrative and legal methods of land compliance by all land relations participants. State control authorities have not only to regulate land conflicts. They also solve contradicting problems in the sphere of land and property relations considering the target purpose of lands, ecological and other factors of land use.

The basic specific principles of state control of the lands use and conservation reflecting its essence and characteristics are:

- securing the protection, rational use and restoration of land resources as the basic national wealth of Ukrainian people;

- preventing combination of the function of control over land use and conservation with the functions of their economic implantation by a single body of executive power;

- priority of ecological interests of society in land resources use over its economic interests;

- connection of high economic efficiency with ecological security of land use;

- full compensation of damages and harms caused by violation of laws dealing with land use conservation.
Within the state control over land use and conservation another vital tool is monitoring of agricultural lands fertility and agro-chemic certification of agricultural lands.

\section{BUILDING LAND ADMINISTRATION SYSTEM}

One of the major problems of ineffective land policy as the basis of economic and social life in Ukraine is the absence of integrated land information system that support decision making towards sustainable development. It is evident, within the period of great land transformation which witness grandiose land redistribution and privatizations, reorganizations of real object of land relations cannot do without the reliable information.

The basic source of such information is the state land cadastre. The land cadastre designation is to secure the state power and local power bodies, physical and juridical persons with information necessary for effective land resources management and organization of rational use and protection.

According to the land legislation, state land cadastre is a single state geo-information system of data of land lying within Ukraine's state borders, their target purpose, limitations in their use, as well as data of quantitative and qualitative description of lands, their valuation, land distribution among owners and users (Law "On State Land Cadastre, 2011).

System of national land cadastre in Ukraine is forming under the World Bank Project "Rural Land Titling and Cadastre Development" which foresees aerial photography and production of basic and index cadastral maps for the whole territory of Ukraine, issuance of state deeds of land parcel ownership (World Bank). However, the authorities took the heading towards the creation of a two-component system, which does not remove the risks of preservation of all the drawbacks of the present one (including inter-agency rivalry for control of financial flows and administrative rent, opportunities for "manual management" of land resources etc.) and does not guarantee the enhancement of its efficiency. Formation and development of the two systems can take place on different technical platforms, with different speed, which, in case of poor standardisation, complicates regulation of information flows among them and undermines promptness of actualisation of information in their databases (even if such exchange is formalised and not done "on request").

Currently, Ukraine has a multi-element inefficient cadastral and registration systems not meeting interests of users, including the state, since it in fact cannot be used for proper management of land resources, calculation and collection of the economically reasonable payment for the land (land lease) and/or immovable property tax.

For instance, in the Doing Business international index in the component "Registering property" released in 2012 , Ukraine ranked $166^{\text {th }}$ out of 183 countries of the world. At that, the number of procedures necessary for registration is -10 , their duration is 117 days, and cost $3.9 \%$ of the registered property value (Doing Business). For comparison with its neighbours that start land reform after Soviet Union's collapse the 
smallest number of property registration procedures was one for Georgia (period - 2 days) and 4 and 5 for Belarus and Armenia respectively.

\section{CONCLUSION}

The above gives grounds to note stockpiling of many unresolved problems in the field of land relations that deadlocked reformation processes. The Land Code of Ukraine effective since January 1, 2002, generally provides rather a directive legislative framework for solution of problems in land relations. However, it covers not all issues related with operation of the land market. Moreover, a considerable number of acting legislative norms are outdated and a lot of them have controversial nature.

Evidently, Ukraine has no comprehensive strategy of state land policy to begin a finish the land reform and ensure effective use of land on the principles of sustainable development. The country does not possess infrastructure of agricultural land market. The state seems to pay attention primarily to the fiscal and political aims. It solves the problems of re-distribution of land ownership, creating the new class of land owners, collecting land taxes with lack of attention to governance of lands as the major national wealth.

Furthermore, the basic land management instruments - land development of agricultural lands lost its importance in the last years and only limited kind of projects are developing now. As a result the state lost control of crop rotation. That leads to irrational, often excessive anthropogenic and technogenic load on land, deterioration of the environment.

It is also necessary to change the approaches for building land administration system in Ukraine. First of all, it is needed to combine all the information about land parcels (land cadastre) and property (town planning cadastre). It helps to decrease an amount of registration procedures and period of property registration. Secondly, it is vital to join the information from registries of mortgages, prohibitions in disposition of property as well as land monitoring information which is part of the general environment monitoring. Thirdly, for building comprehensive land administration system it is important to attached the information about the use of territories of wild nature lands fund, national ecological network and regional cadastres of natural resources. And finally, the operations of the land administration system must be transparent, with safe and easy access to the land market and low cost for all participants.

Ukraine may play an extremely important role in supply of global provision security. But, to fulfil the plan it is very important to complete formation of market preconditions for introduction of agricultural lands into economic circulation, establish transparent competitive land market, legal regulation of questions of land trade as well as to improve investment climate in our country.

\section{REFERENCES}

State Agency of Land Resources of Ukraine: http://www.dazru.gov. ua/terra/control/uk/publish/article?art id=134612\&cat id=97786

Law “On Land Development (2003): http://zakon1.rada.gov.ua/ laws/show/858-15
Law “On State Land Cadastre (2011): http://zakon2.rada.gov.ua/ laws/show/3613-17

World Bank: http://web.worldbank.org/external/projects/main

Doing Business: http://doingbusiness.org/data/exploreeconomies/ ukraine 
